\title{
Defending Palestinian Rights in the Trump Era and Beyond
}

\author{
Yousef Munayyer
}

This chapter explores the challenges and opportunities presented for Palestinian rights work in the United States in the era of Donald Trump and beyond. It argues that Trump's election paradoxically enhanced the momentum for American support for Palestinian rights and for the Boycott, Divestment, and Sanctions (BDS) movement that seeks to hold Israel accountable for its treatment of Palestinians. Generating greater support for Palestinian rights in the United States remains a function of the nature of US-Israel special relations as much as the ability of Palestinian activists to expose the intersections between the Palestinian struggle and the struggle against racism in the United States more generally. Palestinian rights advocacy also remains tied to the ability of the Palestinian national movement to reframe the Palestinian struggle from one that is confined to implementing a defunct two-state solution to one that affirms and protects their rights, irrespective of whatever solution is proposed. By reviewing the history of activism for Palestine in the United States over the past two decades, and the opportunity that Obama's election in particular opened for talking about race and equal rights, this chapter explains why a rights-based approach for defending Palestinian rights has greater prospects for success today than ever before.

\section{POLITICAL ACTIVISM FOR PALESTINIANS IN \\ THE UNITED STATES SINCE 2001}

Advocacy for the Palestinian cause in the United States has a long history. Before the 1967 war, organizations such as the Arab National League and the Institute for Arab American Affairs focused on representing the Palestinian cause as part of the Arab struggle for independence from Western domination. ${ }^{1}$ After the 1967 war, new organizations emerged, such as the Organization of Arab Students, the Arab American University Graduates, and eventually the American Arab 
Anti-Discrimination Committee and the Arab American Institute. ${ }^{2}$ These organizations focused their work on explaining the Palestinian plight to an American public and media that portrayed Palestinians through a stereotypical, simplistic lens-as terrorists. Some of these organizations also tried to lobby and generate support in the US Congress for a Palestinian state on the West Bank and Gaza in light of the Palestine Liberation Organization's declaration of independence, its recognition of Israel, and UN Security Council Resolution 242 in 1988. The advocacy work of these organizations, though, often came up against a special glass ceiling: despite an organized effort at the grassroots level, impact on policy was limited by influential pro-Israel interest groups who had developed strong relationships with policymakers.

With the collapse of the Camp David negotiations in 2000 and the eruption of the Second Intifada, a number of activist organizations came together to create the US Campaign for Palestinian Rights (USCPR). ${ }^{3}$ Founded in 2001, this campaign became a coalition of over three hundred member groups across the United States working for Palestinian rights. It includes organizations large and small of various identities and in various locations across the country. At first, USCPR focused its efforts on ending American military aid to Israel by trying to impact policy makers in Washington, DC. With the advent of the Boycott, Divestment, and Sanction movement in 2005, USCPR took a new approach-one that sought new alliances and aimed at generating a grassroots approach that was seen as having more potential to succeed in impacting American policy on Palestine.

\section{THE BDS CALL AND THE MOVEMENT FOR PALESTINIAN RIGHTS IN THE UNITED STATES}

The movement for Palestinian rights is a global one, and it is not new. Its growth in the United States has been shaped both by the political objectives set by the Palestinian national movement as well as by the nature of US-Israel relations. The US-Israel relationship is the single most important relationship with a country or group of countries that Israel has. Often referred to as a "special" relationship, the US-Israel relationship has paradoxically become the backbone of Israel's human rights abuses against the Palestinians. Without American support, it is hard to imagine how Israel could continue its extensive violations of Palestinian human rights with impunity. The traditional channels of advocacy, particularly as they relate to lobbying Congress and/or the White House, were thus extremely difficult for Palestinians to access and navigate. For this reason, the work of the USCPR has been very challenging. Whereas pro-Israel advocacy groups like American Israel Public Affairs Committee (AIPAC), the Anti-Defamation League (ADL), the American Jewish Committee, and many others, have invested heavily in developing and maintaining relations between Washington and Tel-Aviv for decades, such access to US government circles was very difficult for pro-Palestinian advocates. 
No matter how many letters were written to Congress, how many members of Congress or their staff privately told Palestine rights advocates, "I agree with you, but if I do anything on this, it will cost me dearly," how many phone calls were made by constituents to members' offices-the efforts all came to naught. This had a very discouraging and demoralizing effect on activists engaged in Palestinian rights advocacy.

The Palestinian call for BDS, adopted by over 170 organizations in the West Bank and Gaza in 2005, provided a unique opportunity for Palestinian advocacy work in the United States. ${ }^{4}$ While the idea of divestment had existed before 2005 and indeed, divestment campaigns were being organized and even won in campuses prior to the 2005 call, the call was the first time that the use of these tactics in a Palestinian-led framework was formalized, thanks to its endorsement by over 170 civil society organizations in the West Bank and Gaza. It is no exaggeration to say that the embrace of these tactics by Palestinian rights activists in the United States had a revolutionary impact on the movement. The call gave activists new ways to organize, new spaces in which to organize, new targets, and, most importantly, an opportunity to win. Within USCPR and outside it, activists started thinking that it was perhaps too difficult at the moment to get the US government to address its complicity in Israeli abuses-but what about the complicity of various levels of society below the government level? There was a push for highlighting how individual, community, organizational, institutional, and local government complicity in Israel's violation of Palestinian rights could be articulated in specific campaigns aimed at specific targets. These campaigns could operate in an arena with far less competition than in the halls of Congress, making success far more achievable. This quickly translated to optimism, engagement, buy-in, commitment, and the desire to do more campaign-related work. An effort that had become debilitating and discouraging visibly became dynamic, energizing, and empowering instead.

This grassroots approach also disarmed Israel and its advocates of the ability to discredit their opponents as "terrorists," which had become a particularly potent weapon in post-9/11 America. Those organizing and advocating boycott campaigns were engaged in explicitly nonviolent action. Further, boycott campaigns helped shift the focus away from a nationalist framing of the conflict that pitted Israelis against Palestinians - a framing that posed a number of challenges, including that uncommitted Americans might be reluctant to take sides. Now, the conflict began to be framed as about the average American's own complicity in Israel's human rights abuses against Palestinians.

For all these reasons, BDS campaigns have seen numerous successes in the past twelve years, as can be seen from the list of "BDS Wins" on the USCPR website. $^{5}$ The sheer diversity of victories is impressive: corporate divestment victories, church divestment victories, cultural boycott victories, university boycott victories, professional association victories, and the list goes on. As well, the pace of victories has accelerated over time. In the early years after the BDS call, victories 
were less prevalent, but in recent years, they have been increasingly frequent. The USCPR used to spend more time helping groups start campaigns; now, selfstarting campaigns take off around the country, sometimes thanks to preexisting resources but often also out of the initiative of local organizers, without any support from the USCPR. Now much more of the USCPR's time is spent coordinating and providing support for campaigns that are up and running on their own.

The rights-based activist approach for defending the Palestinian cause in the United States has proved to be more productive than the pre-20oo efforts, which focused on the Palestinian demand for a state. Instead of confining itself to explaining and defending the Palestinian quest for a separate independent state in the West Bank and Gaza, a cause which is hard for outsiders to identify with, the USCPR opted to advocate for restoring denied human rights. This approach proved far easier for people, particularly Americans, to identify with and support. Furthermore, the rights-based approach exposed the pernicious nature of nationalism and specifically what Zionism, an ethnic nationalism, meant for Palestinians. At a moment when a growing political divide is emerging around the world between ethnic nationalism and multiculturalism, this rights-driven approach highlights the dangers of ethnic nationalism and the importance of defending the Palestinians' struggle for equal rights.

\section{THE ZIONIST WHITE SUPREMACIST:}

\section{FROM BALFOUR TO TRUMP}

Revisiting the Balfour Declaration through the lens of the current moment allows us to understand how the tension between ethnic nationalism and multiculturalism has lain at the foundation of the question of Israel/Palestine from the outset until the present day.

Though he may be most known for aiding the Zionist cause in 1917, it is often overlooked that Arthur Balfour, prime minister of the United Kingdom from 1902 to 1905 , was a white supremacist. He made that clear in his own words. In 1906, the British House of Commons was engaged in a debate about the native Black population in South Africa. Nearly all the members of Parliament agreed that the disenfranchisement of Blacks in South Africa was evil. But not Balfour, who was virtually the sole parliamentarian to argue for it, using these words: "We have to face the facts. Men are not born equal, the white and black races are not born with equal capacities: They are born with different capacities which education cannot and will not change."

But Balfour's troubling views were not limited to Africa. In fact, despite his now-iconic support for Zionism, he was not exactly a friend to the Jews. In the late nineteenth century, pogroms targeting Jews in the Pale of Settlement in imperial Russia had led to waves of Jewish flight westward, to England and the United States. This influx of refugees led to an increase in British anti-immigrant racism 
and outright anti-Semitism - themes not unfamiliar to us today. Support for political action against immigrants grew as the English public demanded immigration control to keep certain immigrants, particularly Jews, out of the country.

In 1905, while serving as prime minister, Balfour presided over the passage of the Aliens Act. This legislation imposed the first restrictions on immigration into Great Britain, and it was primarily aimed at restricting Jewish immigration.

It may seem astonishing that Balfour, whose support of the Zionist cause has made him a hero among Jews, would have implemented anti-Jewish laws. But the truth is that his support of Zionism stemmed from the exact same source as his desire to limit Jewish immigration to Britain. Both can be traced back to his white supremacist beliefs. Balfour lived in an era of stirring nationalism, highly defined by ethnoreligious identity. Because of these sentiments, the early twentieth century was a time when ostensibly liberal Western nations struggled with the challenge of incorporating Jewish citizens into their fold. The Zionists provided Balfour with a solution to the challenges that Jewish citizens posed to his ethnonationalist vision, a solution that didn't force him to reckon with them. Instead of insisting that societies accept all citizens as equals, regardless of racial or religious background, the Zionist movement offered a different answer: separation. Balfour saw in Zionism not just a blessing for Jews, but for the West as well. As he wrote in 1919 in his introduction to Nahum Sokolow's History of Zionism, the Zionist movement would "mitigate the age-long miseries created for Western civilization by the presence in its midst of a Body which it too long regarded as alien and even hostile, but which it was equally unable to expel or to absorb." By giving Jews a place to go to, Zionism seemingly solved two problems at once, in Balfour's mind. Balfour's support of Zionism was motivated to an extent by his desire to protect Britain from the negative effects, the "miseries," of having Jews in its midst. Rather than protecting the rights of one of its minorities, Britain could simply export them, or at least, not import any more. Needless to say, this view of Zionism is steeped in the same kind of white supremacy as Balfour's view of South Africa's Blacks. Yet, rather than solving the problem of how to handle a minority living in a white-majority country, the Balfour Declaration just shifted the same problem to a different geography.

For the tension between ethnonationalism and equality is equally present in Israel/Palestine. The Israeli state rules over the fate of millions of Palestinians who either have no right to vote, are treated as second-class citizens, or are refugees denied repatriation. Today, it is Israel that views Palestinians as a "demographic threat" and sees "the presence in its midst of a body which it too long regarded as alien and even hostile, but which it was equally unable to expel or to absorb," as Balfour put it. ${ }^{8}$

That Balfour's legacy of supremacy persists today is no accident. It has lent itself to an imperial project that allowed the Jewish national movement to assert its right to national self-determination while denying the same to the native non-Jews. 
Remarkably, Balfour was unabashedly aware of the hypocrisy of his stance. "The weak point of our position of course is that in the case of Palestine we deliberately and rightly decline to accept the principle of self-determination," he wrote in a letter to the British prime minister in 1919. "We do not propose even to go through the form of consulting the wishes of the present inhabitants of the country ... the 700,000 Arabs who now inhabit that ancient land."10

Those Arabs, of course, made up approximately 90 percent of the population in 1919. Therein lies the fundamental problem that continues through this day, just over one hundred years later. Palestinians are denied the right to have rights because from the outset, their views, their human rights, and indeed their very humanity, were consistently seen as inferior to those of others. That was clear in Balfour's perspective and the British Mandate's policy. And it persists in one form or another in many of the policies of the state of Israel through this day.

Today as much as in 1917, the battle between ethnonationalism and equality, between particularism and universalism, has risen to the foreground, from Donald Trump's rise in the United States to Boris Johnson's Brexited Britain. The ideology that Trump rode into power favored a similar herrenvolk nationalism. It holds that a country is for a people, not for many peoples. Zionism fits this worldview very well. There is a crystalizing alignment taking place and it is happening globally. Israel, which has sold itself in the west as a liberal democracy, is fully and wholeheartedly aligning with reactionary right-wingers across the globe. Exposing this to those in liberal and progressive circles in the United States who have not yet taken a stand on Palestinian rights was one of the key tasks of activists for Palestine in the Trump era.

\section{THE POLITICAL CONTEXT FOR PALESTINIAN RIGHTS BEFORE THE 2016 US ELECTION}

To fully appreciate the meaning and gravity of the reactionary Trump political moment, it is crucial to understand the political moment it was reacting to and the growing partisan divide that developed in the United States. During the Obama era, despite his stalwart support for Israel, on par with or beyond that of his predecessors, an unprecedented shift in public opinion on Israel occurred in the United States. This shift followed largely partisan lines, itself a significant development given the prior American consensus regarding Israel; even when Republicans and Democrats couldn't agree on whether it was night or day, they always agreed on Israel. Now, suddenly, this was starting to change. Although the Democratic party, including under the Obama administration, remained a staunch supporter of Israel (indeed securing it the largest military financing agreement in history), the Republican party, together with right-wing Israelis, tried to portray itself as the only reliable ally of Israel. At the same time, Democrats began to be torn apart between a values-driven base, alienated by the horrors of apartheid on the 
ground in Palestine, and a traditional political and donor class who favored maintaining the bipartisan status quo.

This change took root for several reasons. The first was Obama the person. Barack Hussein Obama had been the first Black person elected as president of the United States. Many Israelis simply could not get past his middle name or the fact that his father was Muslim or that he had spent some time in Indonesia growing up or that he once had a dinner conversation with Edward Said and was acquainted with Rashid Khalidi. Obama was always viewed with suspicion in the highest levels of Israeli government. Michael Oren, the Israeli ambassador to the United States, wrote that "From the moment he entered office, Mr. Obama promoted an agenda of championing the Palestinian cause."11 Oren, the representative of the Netanyahu government, would chalk this up to Obama's "ties to Indonesia and the Muslim villages of Kenya." ${ }^{12}$ The right-wing Israeli government believed that Obama sympathized with the Palestinian narrative more than the Israeli narrative.

The second factor was Benjamin Netanyahu. Netanyahu's premiership in Israel essentially overlapped with Obama's presidency for all but a few months. Each government Netanyahu formed was a right-wing government, strongly supportive of settlement expansion, which caused friction with Obama's Washington as they spoke of advancing Israeli-Palestinian peace negotiations. This tension was evident from the outset of the relationship between the two leaders, and Netanyahu's way of dealing with it was to change the subject away from peace, settlements, and Palestinian rights to Iran.

The third factor is the Iran nuclear deal. Obama viewed the problems of the Middle East in a way that the Israelis did not like. He sought to stabilize it not through massive deployment, but through the pursuit of political agreements, and he saw an opening with Iran that allowed him to pursue the Joint Comprehensive Plan of Action or JCPOA, which would bring Iran in line with its commitments under the nuclear non-proliferation treaty. While this would result in an unprecedented inspections regime for Tehran's nuclear program, it would also mean that the Iranian government would be given a path out of the isolation that the international community had imposed on it. Netanyahu, and many in Israel, who see no option other than eventual regime change in Iran, viewed this as a mistake and worked as hard as possible to torpedo the Iran deal. On Obama's national security agenda, the Iran deal was seen as a significant policy achievement that advanced American national security interests while also keeping a promise Obama had made on the campaign trail about his willingness to talk to the Iranians and advance relations out of mutual respect. For Obama's opponents, some of whom accused the president of being too kind to adversaries of the United States and others who claimed he was not an American and was seeking to subvert the nation from the inside, the Iran deal was fuel for their fire. Many of Obama's supporters, though, not only agreed with the Iran deal for its national security objectives but also grew angry at the subtle, and not so subtle, allegations of treason against their president, which 
they often saw as racially coded or motivated by racism. Obama's election reflected a growing shift in approaching questions of race and white entitlement, the initial manifestations of a minority-majority America. Though when it came to policy, the Obama administration was not very different than others toward Israel, the idea of America that an Obama victory portended clashed with the very ethos of Israel, which is rooted in ethnonationalism and is maintained through discrimination. The partisan divide between Democrats and Republicans grew just as these ideas were coming into sharper contrast.

\section{NARRATIVES OF RACE, BELONGING, AND MULTICULTURALISM IN THE UNITED STATES}

Pro-Israel advocacy in America has always relied not just on Jewish Zionist voices or institutions but also on Evangelical Zionists, a demographic that has for generations been the base of the Republican Party. But it was more recently, during the two Bush administrations between 1988 and 2008, that this constituency really started to flex its muscles. ${ }^{13}$ The confluence of multiple American wars in Muslim countries, 9/11, the "War on Terror," and the Second Intifada all helped consolidate a "clash of civilizations" narrative that dominated the political discourse on the right and beyond. The discourse was clear about the axes of good and evil: predominantly white, Judeo-Christian civilization was on former side; Islam, on the latter.

The election of Barack Obama, the first African American US president, brought to the fore the first physical manifestation of the minority-majority divide in American politics and future. Among the immediate reactions to Obama's triumph were birtherism, the Tea Party, and a narrative that undergirded both: "Obama isn't one of us." These reactionary movements shared this core analysis with a more intellectual-seeming group. In right-wing neoconservative circles, the same narrative was congealing around Obama and one core issue: Israel. Obama, they would argue, was out of step with tradition, an outsider to the realm of the special relationship between the United States and Israel, and one whose intentions could not be trusted. Take, for example, a book published in 2009 by National Review writer Michael Ledeen, called Obama's Betrayal of Israel. For others, one question loomed large: Does Obama feel it in the kishkes for Israel? ${ }^{14}$

Obama, of course, was as pro-Israel as any of his predecessors; he also received the support of the majority of Jewish American voters, who rank Israel as their fifth most important issue. ${ }^{15}$ But that didn't stop certain pro-Israel voices on the right, like Charles Krauthammer, who trumpeted, "It's Obama vs. Israel." ${ }^{16}$ Searching for the source of Obama's hatred of Israel, Krauthammer wondered if it stemmed from Obama's penchant for "appeasing enemies while beating up on allies" or from his desire to "heal the breach between Christianity and Islam ... and has little patience for this pesky Jewish state." 
Over in The Weekly Standard, Bill Kristol argued that Obama was angry, "accelerating both his appeasement of Iran and his attacks on Israel." But there was good news: "The Republican Party and the conservative movement-and most of the American people-stand with Israel and against President Obama." ${ }^{17}$ Kristol also set up the Emergency Committee for Israel, a right-wing attack operation intended to counterbalance J Street, the moderate-in-comparison American Jewish Zionist advocacy group, which was seen as giving Obama Jewish cover. The emergency? It was Hussein Obama, as robocalls supporting Netanyahu's reelection in Israel called him. ${ }^{18}$ After the 2016 election, the Emergency Committee for Israel changed its name to the Committee for Israel. It literally declared the emergency over once the first Black president was replaced by the white-supremacist-in-chief, Donald Trump. According to Bret Stephens, Obama not only "betrayed” Israel, but also systematically failed to oppose everyone from the Iranian regime to Bashar al-Assad to Russia to the Muslim Brotherhood. Stephens wrote that the "most betrayed" by Barack Hussein Obama, the first African American president, was "Americans."19

The narrative flowed back and forth between these voices and others on the right, like Robert Spence, Dick Cheney, Sean Hannity and Alan West, who wrote for example, "The barbarians are indeed at the gate, but there are also traitors within our ranks. If Barack Obama goes to the UN Security Council and drops the veto support for the two-state solution-I believe we will see the latter enable the former." 20

Likewise, Mike Huckabee and Newt Gingrich, two of President Trump's early supporters, helped carry the tune of dog whistles. Gingrich argued that Obama "is so outside our comprehension" that understanding him required knowing "Kenyan, anticolonial behavior." ${ }^{21}$ Mike Huckabee told Fox News viewers that everything Obama “does is against what Christians stand for, and he's against the Jews in Israel. Furthermore, argued Huckabee, "The one group of people that can know they have his undying, unfailing support would be the Muslim community. And it doesn't matter whether it's the radical Muslim community or the more moderate Muslim community."22

Casting Obama as a traitor to the orthodox "Judeo-Christian" position on Israel had a deeper impact than these pundits reckoned with. This framing is well illustrated in an article written by Jennifer Rubin in The Washington Post with the headline, "Why It's Correct to Label the Obama Administration 'Anti-Israel." Rubin concluded that the Obama administration was "the most anti-Israel in history," a "disloyal, unhelpful ally." Her article, which was typical of her output regarding Obama throughout the eight years of his presidency, had a ripple effect. The piece was amplified on the online magazine Breitbart News, which Steve Bannon, its cofounder and later a chief strategic advisor to Donald Trump, called the "platform of the alt-right." 23

In other words, the white supremacist base saw no contradiction between Rubin's analysis of Obama and Israel and their own weltanschauung. And this 
is exactly the point-not only did these pundits not contradict the ideological undercurrent of the alt-right, they provided a piece of the paradigm, with their insistence over and over on an "us-versus-them mentality."

The fight over the Iran deal, during which much of this narrative swirled, put Israel, Republicans, Islamophobes, and racists of various stripes on one side and the president, Democrats, and multiculturalists on another. It came to a climax when the Israeli Prime Minister Benjamin Netanyahu secured an invitation to speak before a joint session of the American Congress through the Republican speaker of the house, circumventing the White House, purely for the purpose of lobbying against the US president's agenda. This meant that the Republican speaker of the house was cooperating with a foreign leader in an effort to derail the signature foreign policy objective of the American president. As a result, a stunning sixty members of Congress, senators and representatives alike, almost all Democrats, chose to skip the speech of Benjamin Netanyahu and held press conferences instead explaining why they had done so. Many of them were members of the Congressional Black Caucus. Speeches of Israeli prime ministers before the American Congress had become known for featuring more standing ovations than the annual State of the Union Address delivered by the president. So for sixty members of Congress to skip out of this high-profile address was stunning rebuke for Netanyahu and a sign of the changing times.

This brings us to the fourth factor that can help explain the unprecedented shift in public opinion on Israel occurring in the United States: what Obama represented, and the challenge this was to many Americans, as the 2016 election of Trump showed. Barack Obama represented a changing America, a majorityminority country that was headed in the direction of more people of color assuming decision-making roles. Obama represented an ethos that would be at the center of the political battle boiling in the next election. That ethos is one of civic belonging; one that prioritizes democracy over identity. American is an idea, not a color, ethnicity, or religion. America does not cease to exist if it no longer has a white Christian majority. The same cannot be said for the Israeli ethos, however. This is an ethos that prioritizes identity over democracy. Obama represented an America that was becoming more demographically diverse and was embracing this diversity. Israel, on the other hand, considers demographic changes existential threats, a view Trump and his allies propagate with regards to the United States as well.

\section{THE ELECTION OF TRUMP IN 2016}

The 2016 US Presidential election was probably the most covered and most followed political contest in modern history. It was a campaign unlike any other, pitting the most insider of insiders, Hillary Clinton, against the most unorthodox of outsiders, Donald J. Trump. Neither of them was particularly good on Palestine or a friend to the BDS movement. Hillary Clinton made a commitment on the 
campaign trail to combat the BDS movement, in large part as a response to her major donor, Haim Saban, who has made fighting BDS a priority. Donald Trump's pro-Israel bona fides were laid out at the annual AIPAC conference and in many statements before or after. ${ }^{24}$

While activists for Palestine in the United States were not expecting much from Trump, most began thinking about how advocacy work for Palestine would change under his presidency. Trump rode to power on a wave of nativist, xenophobic white nationalism that would continue to be empowered after his victory. Trump won despite making attacking the press a cornerstone of his campaigning and despite his pernicious policies towards immigrants and refugees. Some of his key advisors had a "clash of civilizations" mindset that advocated for eternal war with Islam. Some think tanks friendly to Trump had made combating BDS a priority, including through attacking Muslim American organizations that practiced BDS, like American Muslims for Palestine, which is part of the USPCR, and was subjected to hostile legal targeting.

\section{THE NETANYAHU/TRUMP BROMANCE}

Despite uttering words about neutrality between Israel and Palestine early on in his campaign, candidate Trump soon made very clear he would veer further right than any previous major-party presidential candidate before him on this issue. Not only did he state he would recognize Jerusalem as Israel's capital, but he brought onto his team as advisers on the matter two right-wing pro-Israel advocates, David Friedman and Jason Greenblatt. ${ }^{25}$ Both would later play key roles in the Trump administration's relations with Israel, the former as US ambassador to Israel and the latter as Middle East peace envoy.

While Trump continued to attack minorities, he also continued to embrace Israel and in particular Benjamin Netanyahu even before officially taking office. This was clearly seen in December 2016, when he was president-elect and the UN Security Council was voting on a resolution to condemn settlements, which Obama had ultimately permitted to pass by withholding the US veto. Netanyahu worked to stop the resolution, and when the White House refused to commit to veto it, Netanyahu called Trump. Trump then called Egypt's Sisi, whose ambassador had introduced the resolution, and Egypt withdrew it. However, four other countries were prepared to move ahead with it, and the vote ultimately happened with a US abstention. Trump, as always, let his thoughts be known to the world on Twitter, slamming the Obama administration for throwing Israel under the bus and promising that things would be different after January 20, inauguration day. During this time, he also promised to move the US embassy to Jerusalem. Netanyahu promptly thanked him for his support and tweeted that he looked forward to the new relationship. ${ }^{26}$ When President Trump made clear he wanted to pursue an even bigger wall to prevent immigrants from coming into the United States from 
Mexico, Netanyahu tweeted that Israel had built a wall and walls work. Trump would soon cite him in a TV interview. ${ }^{27}$ Shortly after Trump's inauguration on January 20, it was announced that Netanyahu would be the first foreign leader to officially visit the White House after Prime Minister Theresa May of the United Kingdom. Netanyahu's trip was planned for February 15.

\section{THE LOVEFEST DROVE THE WEDGE FURTHER}

Early in his presidency, Trump was a remarkably unpopular figure in the United States and only becoming more despised, particularly among Democrats, including those who did not support Palestinian rights or BDS. Being in opposition to Trump was where all the energy, power, and dynamism was. Being able to brand Israel and Benjamin Netanyahu as Trump allies was a way to continue to open eyes to their pernicious alliance in progressive and liberal circles in the United States. The two leaders were largely doing this work on their own. But activists made highlighting their partnership a central part of their advocacy during this time.

Further, the Trump/Netanyahu love affair sent a shock through much of the American Jewish community, which votes overwhelmingly liberal. Trump's campaign brought all sorts of white nationalists out of the woodwork, leading to a spike in both Islamophobic and anti-Semitic incidents. Yet at the press conference between both leaders, the leader of the "state of the Jewish people" provided backing when Trump faced a question about his campaign's role in fueling anti-Semitism. This rubber-stamping attitude was once again on display when Netanyahu's government retracted a statement condemning an anti-Semitic ad targeting George Soros, an Israel critic and philanthropist, in Hungary. Or when Netanyahu's son Yair and the head of the Israeli American Coalition, Adam Milstein, shared social media memes attacking Israeli critics using anti-Semitic tropes.

Netanyahu's coddling of global right-wingers has been a constant theme in his foreign policy, and it only intensified during the Trump era. Netanyahu provided cover for the Polish government after it passed a law criminalizing suggestions that Poland had any complicity in Holocaust deaths and drew rebuke from the Holocaust museum in Israel. ${ }^{28}$ He similarly was criticized for providing cover for Lithuania, despite the fact that it continues to honor Nazi collaborators. ${ }^{29}$ In recent years, Netanyahu also gave a speech in which he blamed a Palestinian, not Hitler, for inspiring the Holocaust. ${ }^{30} \mathrm{He}$ welcomed a visit to Israel by the right-wing Rodrigo Duterte of the Philippines, who compared himself favorably to Hitler. ${ }^{31}$

When the US embassy was opened in Jerusalem on May 14, 2018, evangelical Christian pastors who have anti-Semitic track records spoke at the ceremony and were warmly welcomed by Israeli officials. More recently, Netanyahu has embraced newly elected Brazilian President Jair Bolsonaro, an outspoken supporter of military rule and torture, who also pledged to move Brazil's embassy to Jerusalem and close the Palestinian diplomatic office in Brazil. Netanyahu is shrewdly calculating 
that he can advance Israel's diplomatic agenda-thwarting accountability for Israel's historic denial of Palestinian rights - around the world, using the far right as a conduit. This alignment between Zionists and right-wing bigots, anti-Semites, and white supremacists has a long history.

\section{TRUMP'S ANTI-DEMOCRAT AND ANTIDEMOCRACY MIDDLE EAST POLICY}

The Trump administration's embrace of Benjamin Netanyahu and the Israeli right has catalyzed the process of making the issue of Israel a partisan one in the United States and helped turn away many Democrats, but Trump has also pursued what can be called an antidemocracy policy when it comes to Israel/Palestine. This approach sought to normalize Israeli apartheid, wherein millions of Palestinians are denied the right to vote, by having unelected Gulf Arab leaders recognize Israel despite the overwhelming opposition of Arab publics. ${ }^{32}$

In the beginning of 2020 and after several years of waiting, the Trump administration finally released its peace plan. Before doing so, however, it began laying the groundwork with regional allies, most notably Israel, the United Arab Emirates, Saudi Arabia, and Bahrain. This coordination was rooted in what seemed to be the pursuit of a new strategy of using the common interest of an adversarial Iran to bring Israel and Gulf states together. Doing so, despite the fact that Arab publics opposed the idea, would foster normalized relations between Israel and the Gulf states. This would in turn break the Arab consensus around the Arab Peace Initiative and upend the established sequence of land for peace, weakening what little leverage the Palestinians had and pressing them to accept an apartheidlike outcome instead of an independent state.

When it was revealed, the Trump peace plan followed the antidemocracy theme by looking favorably on Israeli annexation of 30 percent of the West Bank while still referring to a nonsovereign, disconnected land archipelago as a Palestinian state. ${ }^{33}$ The first stage of the plans' release was programmed to coincide with an economic conference hosted in Manama, Bahrain, in which no Palestinians were officially involved. The political parameters were then released by the administration in January 2020.

The Manama conference in June 2019, which followed the Trump administration's support for the unprecedented Saudi- and Emirati-led marginalization of Qatar two years earlier, made it clear to many that the Trump administration was hoping to work with select Gulf monarchies to press the Palestinians into accepting an apartheid-like solution. While the Trump plan was roundly rejected in the Arab world officially and was met with an Arab League affirmation of the Arab Peace Initiative, that consensus began to shake when the United Arab Emirates announced it would pursue normalized relations with Israel in August 2020. The signing of the Abraham Accords in August 2020 between Israel and the United 
Arab Emirates and Bahrain made official this normalization, to the detriment of Palestinian rights. The Trump administration's overall approach toward the region, as well as its specific initiatives to push Gulf autocracies to help legitimize Israel's ongoing violations of international law and human rights, offer observers a clear contrast between Trump and Israel on the one hand, and the values of rights, pluralism, and equality on the other.

\section{AN AGENDA FOR CHANGE: CHALLENGES \\ AND OPPORTUNITIES IN BUILDING TOWARD \\ THE "S" IN BDS}

While the movement for Palestinian rights has had success over the past twelve years, in many BDS campaigns much work remains as far as getting to the " $\mathrm{S}$ "the sanctions. Getting the US government to level sanctions on Israel would be a game-changer, and the US campaign among others has not shied away from this objective. Rather, it has sought to assess what it would take to achieve this goal, to be realistic about the time it will take, and to build the popular or grassroot support necessary to march down this path and do so unapologetically. The question for activists on Palestine during the Trump era was how to work most effectively toward this ultimate goal. Below I outline what I see as current and future challenges and opportunities for this effort.

\section{Intersectionally Organize}

During the summer of 2014, Israel bombarded Gaza for fifty-five days, killing well over two thousand Palestinians, most of whom were civilians. ${ }^{34}$ The war on Gaza received massive coverage in the United States, albeit primarily filtered through a pro-Israel lens, and was the lead story on almost every day of the summer and in every newscast. But what may be less known outside the United States is that on August 9, just as the war in Gaza was beginning to wind down, Michael Brown, an unarmed eighteen-year-old African American from Ferguson, Missouri was shot to death by a white police officer allegedly while he had his hands up and was turning around to face the officer. He was shot six times in the front. The case ignited long-simmering tensions between the city's majority-black population and the majority-white city government and police. The US media recentered its focus from Gaza to police brutality in the United States and the legacy of racism in American institutions, especially in law enforcement. But the fact that Brown's murder came during the war on Gaza meant that activists in the United States following the news on both traditional and social media were confronted by a striking juxtaposition between state violence aimed at upholding a system of injustice across the world, on the one hand, and right here at home, on the other. As protesters gathered in the streets of Missouri only to be met with harsh police response, activists from Palestine sent messages with tips on how to mitigate the influence of 
tear gas. Others circulated images of the identical tear gas canisters being used six thousand miles apart, made by the same corporation in Pennsylvania. Palestinian keffyahs could be seen in the streets of Ferguson during protests. The connections were just too striking to ignore.

This episode highlights one of many intersectional organizing opportunities that offer a path to building coalitions with groups and movements who are unaware of activism on Palestine and can, in turn, benefit from support from Palestine activists. There are intersections with Palestinian rights issues and various other prominent issues in the United States, including some that came to the fore after Trump's election. For example:

- The same company that helped build Israel's Separation Wall in the West Bank and helped cage Gaza behind a wall was considered to be the frontrunner for the contract to expand Trump's wall to keep immigrants out along the southern border with Mexico. ${ }^{35}$

- The security systems company G4S, which has long been a BDS target, is deeply enmeshed in the American prison-industrial complex. ${ }^{36}$

- Since the 1990s, police exchange programs - many of them organized, facilitated, and funded by the pro-Israel Anti-Defamation League (ADL) - have been organized to take American law enforcement officers to Israel to "build bonds between two peoples fighting terror." But American police already have a tremendous and deadly problem with profiling and brutality and need not learn from Israeli police, who openly and unabashedly embrace racial profiling as a policing tactic. ${ }^{37}$

The opportunities to create alliances and to build support for the issue of Palestinian rights as belonging within the fold of progressive and liberal priorities continued to grow, as can be seen in Michelle Alexander's column in The New York Times ahead of Martin Luther King Jr. Day in 2019. An esteemed author on racial justice, she used her column to issue a clarion call for solidarity with the Palestinian people. She wrote:

Reading King's speech at Riverside more than 50 years later, I am left with little doubt that his teachings and message require us to speak out passionately against the human rights crisis in Israel-Palestine, despite the risks and despite the complexity of the issues. King argued, when speaking of Vietnam, that even "when the issues at hand seem as perplexing as they often do in the case of this dreadful conflict," we must not be mesmerized by uncertainty. "We must speak with all the humility that is appropriate to our limited vision, but we must speak." And so, if we are to honor King's message and not merely the man, we must condemn Israel's actions: unrelenting violations of international law, continued occupation of the West Bank, East Jerusalem, and Gaza, home demolitions and land confiscations. We must cry out at the treatment of Palestinians at checkpoints, the routine searches of their homes and restrictions on their movements, and the severely limited access to decent housing, schools, food, hospitals and water that many of them face..$^{38}$ 
While these changes offer important opportunities for the continued and successful growth of Palestinian rights advocacy in the United States, a number of important challenges must also be addressed.

\section{Reform Anti-lobbying Culture}

An unfortunate byproduct of the success of BDS tactics is that they have directed grassroots energy away from focused engagement with policy-makers in the federal government. As activists get used to working on divestment campaigns targeting a corporation or aiming for a resolution in this church or that university, they are honing organizing skills for those campaigns but not developing the lobbying skills needed for effective government engagement. As I noted earlier, BDS tactics provided something of a refuge for activists who were tired of getting nowhere with Congress, but here is the hard truth: there is no way to sanctions without going through Congress. This means that at some point, that engagement needs to happen, and the sooner it starts the better. This is not to say there is currently no engagement with lawmakers-there is, but there can be much more and there will have to be much more for us to achieve the goals we have set. The anti-lobbying culture that has arisen as a byproduct of focused " $\mathrm{B}$ " and " $\mathrm{D}$ " work makes this more difficult, but the political ground for engagement is also ripe at this moment. A 2017 poll found that some 56 percent of Democrats, along with 41 percent of Americans overall, would support sanctions putting greater pressure on Israel over continued settlement expansion. ${ }^{39}$ Addressing this anti-lobbying culture and correcting it will be a big task for political activism on Palestine in the United States in the years ahead.

It is also important to be clear that while Democrats might have more support among their base for moving in the direction of sanctions over time, elected officials will still have to be pulled in this direction and will not be eager to go there willingly. Democrats, particularly establishment Democrats who have been in office for years, adjusted to a politics of bipartisan consensus of unquestioning support for Israel. That is starting to change and a younger generation of progressive Democrats seems less beholden to this older way of thinking and more in tune with their base.$^{40}$ Further, these newcomers, like Jamaal Bowman and Cori Bush, are winning in primary elections, while others like Rashida Tlaib, Ilhan Omar, and Alexandria Ocasio-Cortez are beating back primary challengers and were elected to congress in 2020. Importantly, this younger generation of progressives is succeeding electorally against candidates supported by significant pro-Israel campaign funds. ${ }^{41}$ For these reasons, it is more important than ever for activists and organizers who turned out of frustration to boycott and divestment and away from engaging elected officials to refocus their energies in that direction and in this moment.

\section{Lawfare}

An additional challenge we have been confronting in the United States in recent years and increasingly today is "lawfare" efforts aimed at repressing the Palestinian 
rights movement by attempting to criminalize BDS tactics. We have seen multiple such pieces of legislation in state legislatures across the United States over the last several years. As of this writing, twenty-seven states have enacted such legislation since $2014 .{ }^{42}$ The US Campaign has organized local coalitions to fight these bills, but not all have been successful. As a group of organizations with a relatively small capacity in comparison to the capacity of those opposing them, local BDS organizers must be careful not to get bogged down in fighting anti-BDS legislation to the point where it becomes all-consuming. Activists are triaging the situation and strategically addressing state legislation, while also working with other civil rights and liberties groups to educate activists about their rights, which is a key component to defeating the chilling effect these proposed laws are designed to have.

Former President Trump notwithstanding, the US Constitution is still the law of the land. By contrast with France, for example, where the state can take draconian steps against BDS activity, in the United States political boycotts are considered free expression that is protected under the first amendment to the Constitution. For this reason, anti-BDS laws in the United States can only go so far before crossing a constitutional line that would open them to a legal challenge. Anti-BDS law drafters have attempted to tiptoe right up to this line in some places, but elsewhere have crossed it. Some state laws require state contractors to sign an oath swearing they will not boycott Israel. In Texas, for example, this led to a schoolteacher and several others being forced to choose between their constitutional rights and their jobs. ${ }^{43}$ Legal challenges have already begun in several states.

In the summer of 2017 , an important battle began against a piece of proposed federal legislation called the Israel Anti-Boycott Act. As originally written, it could lead to civil and even criminal penalties for BDS-type activity, with up to a one million dollar fine and a twenty-year jail sentence. The act was cosponsored by Republican and Democratic senators in an attempt to provide a bipartisan veneer, but in reality it was overwhelmingly supported by Republicans. It was clear it would not have the support needed to pass, and so early on, one of its leading sponsors, Ben Cardin (D-MD) attempted to add it as an amendment to other legislation so it could be snuck through without debate. This attempt failed, and a public debate began.

The American Civil Liberties Union (ACLU) joined several organizations, including the USCPR, to defeat this legislation. This is very important for several reason. First, the ACLU is highlighting the unconstitutional nature of these bills, a view that had been expressed loudly by many but was taken seriously only once the ACLU weighed in. Second, the ACLU is a very well-respected organization, particularly in liberal circles, and the fact that they adopted this cause sent an important political message. Third, the ACLU was the key institutional leader opposing Trump policies that violate human rights, such as the Muslim ban, for example. Once the ACLU weighed in, senators came under increased pressure to end their sponsorship of the legislation, and many expressed a willingness to amend it. Ultimately, enough pressure from a progressive coalition was generated 
to prevent the passage of such legislation in the 115th Congress and the Israel AntiBoycott Act expired in December 2018. Further efforts in the 116th Congress to pass legislation that criminalized boycotts for Palestinian rights have also come under opposition from progressive actors and are unlikely to pass if they continue to include components violating First Amendment freedoms. This consensus has become so significant within the party that the latest party platform, adopted in 2020 , included language specifically committing to uphold first amendment freedoms around boycott efforts.

Legislation is just one part of a repressive effort supported by a network of actors aiming to silence criticism of Israel. These authoritarian tactics belie Israel's image with American audiences as a "democratic ally." Continuing to expose these repressive efforts in partnership with institutions that have been leaders in protecting free expression will be an important feature of the work moving forward. As of this writing, repressive laws aimed at intimidating Palestinian rights activism have been successfully challenged in Kansas and Arizona, where federal courts have sided with the plaintiffs against the states whose legislatures passed anti-BDS bills.

Political progress was also made at the federal level after the shift in power in the House of Representatives in 2018. At the end of 2018, as power was changing hands, there was an effort to rush federal anti-BDS legislation through Congress by attaching it to a spending bill urgently needed to avoid a government shutdown. ${ }^{44}$ But thanks to pressure created by advocacy groups, including the ACLU and others the New York Times editorial board came out against the legislation as did leading Democratic senators Bernie Sanders and Diane Feinstein. ${ }^{45}$

The legislation, the Israel Anti-Boycott Act, did not make it into the emergency spending measure but the high public drama around it encouraged Republican senators to try to force Democrats into choosing between siding with Israel or their base soon thereafter. With a new Congress sworn in at the start of the year, including members Rashida Tlaib and Ilhan Omar, who openly supported BDS, the opportunity for Republicans to use Israel as a political cudgel was heightened. The first piece of legislation considered by the Senate, Bill S.1., included four elements, among them anti-BDS legislation, seen as unconstitutional. Just weeks after the Israeli Anti-Boycott Act controversy, the stage was set again for another political fight over the constitutional right to boycott Israel. While S.1 ultimately passed the Senate, half the Democratic caucus in the Senate voted against it, including almost all the senators who sought the Democratic nomination for president in 2020. In the House, where Democrats had now come into control, the anti-BDS components of S.1. were dead on arrival after the progressive caucus extracted private concessions from House Speaker Nancy Pelosi not to bring forward legislation that would divide Democrats. While the party would not support BDS, and indeed opposed it on record, it also would not support efforts to unconstitutionally confront BDS activism. By the summer of 2020 , that position had made it into the Democratic party platform. 


\section{Building Congressional Support}

There is a need to continue to build support in Congress for standing up for Palestinian rights. In recent years, important gains have been made in this area, even though the energy of the movement has been more campaign-focused and not as focused on engaging government. In 2016, for example, nineteen members of Congress, led by Representative Betty McCollum, signed on to a letter to the Secretary of State demanding that steps be taken to protect Palestinian children whose rights are abused by Israeli policies. The letter even called for holding Israeli military units accountable under the Leahy Law, a provision that would deny aid or training to those units. Other letters have focused on supporting human rights defenders facing falsified charges or calling for investigations into extrajudicial killings.

This may seem unremarkable, but consider that even just ten years ago, it was difficult to get five members of Congress to sign a "Dear Colleague" letter urging continued support for humanitarian aid to Gaza through UN Relief and Works Agency. Much has changed in these ten years. Over time, multiple "Dear Colleague" letters have rallied progressive and liberal members of Congress concerned about Palestinian rights. After the letter-writing of the past decade, it was possible to introduce legislation supportive of Palestinian rights. That happened in late 2017, when Representative McCollum introduced HR 4391, which would condition aid to Israel on its treatment of Palestinian children. Some thirty-one members of Congress have since joined this legislation as cosponsors. While these letters and bills are important on their own, they are also vehicles for building and broadening congressional support.

By way of historical comparison, the first comprehensive bill for sanctions against South Africa was introduced in 1972, but it took a full fourteen years before it could pass. Today with unprecedented numbers of representatives and senators taking steps to defy the intimidation of pro-Israel lobby groups, there is newfound energy to redouble efforts and continue to build. As the number of people supporting Palestinian rights grows, more members feel safe joining. Activists are working to build a core, first among progressive Democrats and then into the mainstream of American politics, of Americans who support Palestinian rightsbecause Palestinian rights are as important as the rights of any other people or group.

\section{THE LONG WALK}

American policy is central when it comes to Israel-Palestine because American support for Israel enables it to act oppressively and with impunity. For many reasons, America's policy toward Israel is a function of a unique set of foreign and domestic interests that have established a long-standing orthodoxy. Today, that orthodoxy is starting to shake as a rights-based advocacy for Palestinians meets an America at a crossroads. Rights-based advocacy approach is uniquely positioned to gain the greatest traction in this American political moment and perhaps beyond. 
While the conditions that can create change in US policy are increasingly beginning to assemble, there should be no doubt that the road ahead remains a lengthy one. Activists and advocates for Palestinian freedom can take comfort in the fact that the rights-based approach, as opposed to nationalist advocacy for partition or statehood, is the shortest path toward the goal because it is most likely to permit the formation of coalitions and alliances in a changing America. As the contrast between the values of freedom, justice, and equality and what Israel is doing to the Palestinian people continues to grow increasingly stark, Americans across the political spectrum will begin to reevaluate US support for Israel. Energy dedicated to sharpening that contrast for American audiences will likely help make the long walk to freedom shorter.

\section{NOTES}

1. Hani J. Bawardi, The Making of Arab Americans: From Syrian Nationalism to US Citizenship (Austin: University of Texas Press, 2014).

2. Pamela E. Pennock, The Rise of the Arab American Left: Activists, Allies, and Their Fight against Imperialism and Racism, 1960s-1980s (Chapel Hill: University of North Carolina Press, 2017).

3. USCPR's original name was the US Campaign to End the Israeli Occupation.

4. "Palestinian Civil Society Call for BDS," Palestinian BDS National Committee, July 9, 2005, https://bdsmovement.net/call.

5. "US BDS Wins," US Campaign for Palestinian Rights, last modified June 2019, https://uscpr .org/campaign/bds/bdswins/.

6. Parliamentary Debates, Commons (July 31, 1906).

7. Michael J. Cohen, Britain's Moment in Palestine: Retrospect and Perspectives, 1917-1948 (London: Routledge, 2014), 11.

8. Cohen, Britain's Moment in Palestine, 11.

9. Arthur Balfour, quoted in Gudrun Krämer, A History of Palestine: From the Ottoman Conquest to the Founding of the State of Israel (Princeton, NJ: Princeton University Press, 2008), 167.

10. Walid Khalidi, From Haven to Conquest: Readings in Zionism and the Palestine Problem until 1948 (Beirut: Institute for Palestine Studies, 1971), 208.

11. Michael B. Oren, "How Obama Abandoned Israel," Wall Street Journal, June 16, 2015, https:// www.wsj.com/articles/how-obama-abandoned-israel-1434409772.

12. Michael Oren, "How Obama Opened His Heart to the 'Muslim World," Foreign Policy (blog), June 19, 2015, https://foreignpolicy.com/2015/o6/19/barack-obama-muslim-world-outreach-conse quences-israel-ambassador-michael-oren/.

13. Howard J. Gold and Gina E. Russell, "The Rising Influence of Evangelicalism in American Political Behavior, 1980-2004," Social Science Journal 44, no. 3 (2007): 554-62, https://doi.org/10.1016/j .soscij.2007.07.016.

14. Jeffrey Goldberg, "The Kishke Debate," The Atlantic, October 23, 2012, https://www.theatlantic .com/politics/archive/2012/10/the-kishke-debate/263981/.

15. Ron Kampeas, "How Barack Obama Won over Jewish Voters-While Irking Pro-Israel Establishment," Jewish Forward, January 18, 2017, https://forward.com/news/360276/how-barack-obama -won-over-jewish-voters-while-irking-pro-israel-establishme/.

16. Charles Krauthammer, "It’s Obama vs. Israel," New York Daily News, March 18, 2010, https:// www.nydailynews.com/opinion/obama-israel-article-1.173095. 
17. William Kristol, "Obama’s Israel Problem," Washington Examiner, January 29, 2015, https:// www.washingtonexaminer.com/weekly-standard/obamas-israel-problem.

18. Niv Elis, "Pro-Likud Campaign Call Warns Voters of 'Hussein Obama," Jerusalem Post, March 15, 2015, https://www.jpost.com/Israel-Elections/Pro-Likud-campaign-call-warns-voters-of -Hussein-Obama-393987.

19. Bret Stephens, "Obama’s Fitting Finish," Wall Street Journal, December 26, 2016.

20. Robert Spencer, "Why Obama Is the Worst President in U.S. History," Jihad Watch, January 23, 2017, https://www.jihadwatch.org/2017/o1/robert-spencer-why-barack-obama-is-the-worst-presi dent-in-u-s-history. Sean Hannity, "Is President Obama Betraying Israel?" Fox News, March 2, 2015, https://www.foxnews.com/transcript/is-president-obama-betraying-israel. Allen West, "Obama Set to Betray Israel Again; When Will American Jews Wake Up?” AllenBWest.com, March 31, 2015, https:// web.archive.org/web/20170904124901/; https://www.allenbwest.com/2015/03/31/obama-set-to-betray -israel-again-when-will-american-jews-wake-up/.

21. Newt Gingrich, quoted in Eric Kleefeld, "Gingrich Promotes Right-Winger D’Souza's Description of Obama as 'Kenyan Anti-Colonial,"' Talking Points Memo, September 13, 2010, https://talking pointsmemo.com/dc/gingrich-promotes-right-winger-d-souza-s-description-of-obama-as-kenyan -anti-colonial.

22. Mike Huckabee, quoted in Michael W. Chapman, "Huckabee: Obama 'Against What Christians Stand For,' Against 'Jews in Israel,' Has 'Undying' Support for Muslims," CNSNews.com, February 10, 2015, https://www.cnsnews.com/blog/michael-w-chapman/huckabee-obama-against-what -christians-stand-against-jews-israel-has-undying.

23. "Washington Post Columnist: Why It's Correct to Label the Obama Administration 'Anti-Israel," Breitbart Jerusalem, January 22, 2016, https://www.breitbart.com/national-security/2016/o1/22 /washington-post-columnist-why-its-correct-to-label-the-obama-administration-anti-israel/.

24. “Read Donald Trump's Speech to AIPAC," Time, March 21, 2016, https://time.com/4267058 /donald-trump-aipac-speech-transcript/.

25. Jason D. Greenblatt, "Joint Statement from Jason Dov Greenblatt and David Friedman, CoChairmen of the Israel Advisory Committee to Donald J. Trump," Medium, November 2, 2016, https:// medium.com/@jgreenblatt/joint-statement-from-jason-dov-greenblatt-and-david-friedman-co -chairmen-of-the-israel-advisory-edciec5ob7a8.

26. "Trump Urges Israel to 'Stay Strong' till January 20," Times of Israel, December 28, 2016, https://www.timesofisrael.com/trump-urges-israel-to-stay-strong-till-january-2o/.

27. William Booth, "Israel's Netanyahu Applauds Trump's Plan for Wall; Mexico Not Pleased," Washington Post, January 27, 2017, https://www.washingtonpost.com/news/worldviews/wp/2017/o1 /29/israels-netanyahu-applauds-trumps-plan-for-wall-mexico-not-pleased.

28. Isabel Kershner, "Yad Vashem Rebukes Israeli and Polish Governments over Holocaust Law," New York Times, July 5, 2018, https://www.nytimes.com/2018/07/05/world/middleeast/israel-poland -holocaust.html.

29. "Despite Honors for Collaborators, PM Praises Vilnius for Holocaust Remembrance," Times of Israel, August 4, 2018, https://www.timesofisrael.com/despite-honors-for-collaborators-pm-praises -vilnius-for-holocaust-remembrance/.

30. "Netanyahu: Hitler Didn't Want to Exterminate the Jews," Haaretz, October 21, 2015, https:// www.haaretz.com/israel-news/netanyahu-absolves-hitler-of-guilt-1.5411578.

31. "Jewish Leaders React to Rodrigo Duterte Holocaust Remarks," BBC, September 30, 2016, https://www.bbc.com/news/world-asia-37515642.

32. For detailed polls on this issue, see Arab Center for Research and Policy Studies, The Arab Opinion Index 2018, https://www.dohainstitute.org/en/Lists/ACRPS-PDFDocumentLibrary/2017-2018\%20 Arab\%20Opinion\%2oIndex\%20Main\%20Results\%20in\%20Brief\%20-\%2ofinal\%20(002).pdf. 
33. I define this as antidemocratic insofar as it advances a racist understanding of the conflict, privileging Israeli right-wing interests and vision, rather than any adherence to international law or human rights when it comes to the Palestinians.

34. United Nations Human Rights Council, "The United Nations Independent Commission of Inquiry on the 2014 Gaza Conflict," United Nations Human Rights Council, June 24, 2015, https:// www.ohchr.org/EN/HRBodies/HRC/CoIGazaConflict/Pages/ReportCoIGaza.aspx.

35. Jonathan Ferziger, "Israeli Company That Fenced in Gaza Angles to Help Build Trump's Mexico Wall," Bloomberg News, January 29, 2017, https://www.bloomberg.com/news/articles/2017-01-29 /israel-s-magal-pushes-for-mexico-wall-deal-as-trump-buoys-shares.

36. Jamilah King, "Angela Davis on Palestine and the Prison Industrial Complex," Colorlines, July 22, 2014, https://www.colorlines.com/articles/angela-davis-palestine-and-prison-industrial-complex.

37. Noah Habeeb and Craig Willse, "US and Israeli Police Are Sharing Violent and Repressive Tactics," Truthout, December 11, 2018, https://truthout.org/articles/us-and-israeli-police-are-sharing -violent-and-repressive-tactics/.

38. Michelle Alexander, "Time to Break the Silence on Palestine," New York Times, January 19, 2019, https://www.nytimes.com/2019/o1/19/opinion/sunday/martin-luther-king-palestine-israel.html.

39. Shibley Telhami and Stella Rouse, "American Attitudes on the Israeli-Palestinian Conflict" University of Maryland Critical Issues Poll, 2017, https://sadat.umd.edu/sites/sadat.umd.edu/files /american_attitudes_on_israel-palestine.pdf.

40. Catie Edmondson, "A New Wave of Democrats Tests the Party's Blanket Support for Israel," New York Times, October 7, 2018, https://www.nytimes.com/2018/10/o7/us/politics/democrats-israel -palestinians.html.

41. Matthew Kassel Jacob Kornbluh, "Money in Politics Is Not Like It Once Was: Will Pro-Israel Donors Adapt?" Jewish Insider, August 17, 2020, https://jewishinsider.com/2020/o8/money-in-politics -is-not-like-it-once-was-will-pro-israel-donors-adapt/.

42. "Anti-Boycott Legislation around The Country," Palestine Legal, 10, 2019, https://palestinelegal .org/righttoboycott.

43. Jacey Fortin, "She Wouldn't Promise Not to Boycott Israel, So a Texas School District Stopped Paying Her," New York Times, December 19, 2018, https://www.nytimes.com/2018/12/19/us/speech -pathologist-texas-israel-oath.html.

44. Emily Cochrane, "Lawmakers Consider Adding Measure Protecting Israel to Languishing Spending Bills," New York Times, December 17, 2018, https://www.nytimes.com/2018/12/17/us/politics /israel-boycotts-government-shutdown.html.

45. Kate Ruane, "Congress Is Trying to Use the Spending Bill to Criminalize Boycotts of Israel and Other Countries," American Civil Liberties Union (blog), December 10, 2018, https://www.aclu.org /blog/free-speech/rights-protesters/congress-trying-use-spending-bill-criminalize-boycotts-israel -and, Editorial Board, "Curbing Speech in the Name of Helping Israel," New York Times, December 18, 2018, https://www.nytimes.com/2018/12/18/opinion/editorials/israel-bds.html. Senator Bernie Sanders, "Sanders, Feinstein Oppose Inclusion of Israel Anti-Boycott Act in Appropriations Bill," press release, December 19, 2018, https://www.sanders.senate.gov/press-releases/sanders-feinstein-oppose -inclusion-of-israel-anti-boycott-act-in-appropriations-bill/.

\section{BIBLIOGRAPHY}

Arab Center for Research and Policy Studies. The Arab Opinion Index 2018. https://www .dohainstitute.org/en/Lists/ACRPS-PDFDocumentLibrary/2017-2018\%20Arab\%20 Opinion\%2oIndex\%2oMain\%2oResults\%2oin\%2oBrief\%2O-\%2ofinal\%2o(oo2).pdf.

Bawardi, Hani J. The Making of Arab Americans: From Syrian Nationalism to US Citizenship. Austin: University of Texas Press, 2014. 
Cohen, Michael J. Britain's Moment in Palestine: Retrospect and Perspectives, 1917-1948. London: Routledge, 2014.

Gold, Howard J., and Gina E. Russell. "The Rising Influence of Evangelicalism in American Political Behavior, 1980-2004." Social Science Journal 44, no. 3 (2007): 554-62. https:// doi.org/10.1016/j.soscij.2007.07.016.

Khalidi, Walid. From Haven to Conquest: Readings in Zionism and the Palestine Problem until 1948 Beirut: Institute for Palestine Studies, 1971.

Krämer, Gudrun. A History of Palestine: From the Ottoman Conquest to the Founding of the State of Israel. Princeton, NJ: Princeton University Press, 2008.

Louis, Willian Roger. Ends of British Imperialism: The Scramble for Empire, Suez, and Decolonization. London: I.B. Tauris, 2006.

Pennock, Pamela E. The Rise of the Arab American Left: Activists, Allies, and Their Fight against Imperialism and Racism, 1960s-1980s. Chapel Hill: University of North Carolina Press, 2017.

Porter, Bernard. Critics of Empire: British Radicals and the Imperial Challenge. London: I.B. Tauris, 2008.

Telhami, Shibley, and Stella Rouse. "American Attitudes on the Israeli-Palestinian Conflict." University of Maryland Critical Issues Poll, 2017. https://sadat.umd.edu/sites/sadat.umd .edu/files/american_attitudes_on_israel-palestine.pdf.

United Nations Human Rights Council. “The United Nations Independent Commission of Inquiry on the 2014 Gaza Conflict." United Nations Human Rights Council. June 24, 2015. https://www.ohchr.org/EN/HRBodies/HRC/CoIGazaConflict/Pages/Report CoIGaza.aspx. 